\author{
JOANNA SIKORSKA \\ Uniwersytet im. Adama Mickiewicza \\ $w$ Poznaniu
}

\title{
CULTURE AND THE WORLDS CREATIVE DIVERSITY
}

\begin{abstract}
Sikorska Joanna, Culture and the World's Creative Diversity [Kultura i globalna różnorodność kreatywna]. Studia Edukacyjne nr 41, 2016, Poznań 2016, pp. 217-226. Adam Mickiewicz University Press. ISSN 1233-6688. DOI: 10.14746/se.2016.41.13
\end{abstract}

The idea that different cultures think differently about cultural aspects of education is clearly seen in Cyberspace, where people converge, discuss and apply new ideas to the educational programs in their home countries. It is because of Cyberspace that our ideas pertaining to culture education changed or shifted from their axis. Cyberspace continues to grow and the growth triggers problems, which is normal considering it is a place where many cultures interact with each other.

As pedagogues and teachers, we should counteract cyberbullying and cyberstalking in Cyberspace and prevent such things from happening in real life. In my opinion, everyone should learn the culture of his/her home country and countries he/she will someday come into contact with. We cannot continue to be blinded by what others say, we need to educate children so that we can be proud of them further down the line. Otherwise children will educate themselves and that can contribute to hate, misunderstandings, prejudice, and anger towards people from other cultures.

This paper will give examples of the diversity of cultures comprising our world and try to show how we can protect and help children by listening to them so that they can understand this diversity, and allow them to be the creators of their own future, which would not be based on prejudice and stereotype.

Key words: culture, cultural diversity, intercultural education, creativity, tolerance

\section{Introduction}

Paul Ricoeur one of the most famous contemporary philosophers stresses that from the moment in which the world, as a result of political transformations, opened itself, becoming a place of extraordinary mobility of people, and thus with the constant contacts with other cultures such questions as "Who am I? Who are the others? Are "they" "bad" people, who we 
should regard as not only others, but also as people "inferior" to us? And maybe those others enrich our personal and collective self with new areas connected with this diversity?, appear more often.

On the one hand, we are witnessing a process of world integration which could, moreover, result in some kind of universalization, if you drown out the superficial uniformity, on the other hand we know that the world is also subject to all kinds of disintegration.

This process is the danger of fanaticism, exposing small differences which become a source of resentment and intolerance, and as a result also saturated in the aggression and violence of conflicts. Increasingly we are seeing two contradictory processes shaping our common world, far-reaching globalization and universalization, as well as particularisms of resentment and conflict.

This makes it difficult to agree and understand that through cultivating our roots and our heritage we can open up to other cultures because human development is based on a cultural dialogue - whose foundation is respect for the diversity that enriches us.

\section{Cultural diversification and its meaning for the dialogue in the contemporary world}

Because of its complex nature the word culture is very difficult to define. One has to agree with Hinkel that there are "as many definitions of culture as there are fields of inquiry into human societies, groups, systems, behaviors and activities". 1

For many people culture would mean art, literature, customs and everyday life peculiar to a certain groups. These can be called the observable symptoms of culture. However, culture also includes invisible features like beliefs, values, norms and attitudes. A definition combing these two aspects of culture is offered by the Encyclopaedia Britannica. It says that culture is a

behavior peculiar to Homo Sapiens, together with material objects used as an integral part of this behavior; specifically culture consists of language, ideas, beliefs, customs, codes, institutions, tools, techniques, works of art, rituals, ceremonies, and so on". ${ }^{2}$

\footnotetext{
${ }^{1}$ E. Hinkel (ed.), Culture in second language teaching and learning, New York 1999, p. 1.

2 https:/ / www.britannica.com/topic/social-science\#ref423691 [date of access: 20.07.2016].
} 
However, for us to better understand its complexity we should also take into consideration other definitions of culture that will deepen the meaning of Britannica's definition. The first will be the classic definition of the anthropologist Edward Burnett Tylor "Culture... is that complex whole which includes knowledge, belief, art, morals, law, custom, and any other capabilities and habits acquired by man as a member of society ${ }^{3 \prime}$ and Brown's definition from a linguistic standpoint "Culture is a way of life and it includes the ideas, customs, skills, arts, and tools that characterize a given group of people in a given period of time". ${ }^{4}$

Fenner claims that not until the $20^{\text {th }}$ century was it possible for people to create their own identity for the first time and it was mostly young people who used this opportunity forming various kinds of subcultures. Culture is a common identity for the members of society or group. Culture influences the world view of its members and the members influence the culture. It is a dialectic process in the dynamic force of culture which takes place in an encounter with foreign cultures. 5

From the presented definitions of culture a lot of terms was reflected in the Universal Declaration on Cultural Diversity.

The UNESCO Universal Declaration on Cultural Diversity was adopted unanimously in a most unusual context - after the events of 11 September 2001 and the 31 ${ }^{\text {st }}$ UNESCO General Conference after those terrible events. It was an opportunity to reaffirm the conviction that intercultural dialogue is the best guarantee of peace and to reject outright the theory of the inevitable clash of cultures and civilizations, because as Koïchiro Matsuura, the UNESCO Director-General, emphasizes "the cultural wealth of the world is its diversity in dialogue". 6

Such a wide-ranging instrument is a first for the international community. It raises cultural diversity to the level of "the common heritage of humanity"7, "as necessary for humankind as biodiversity is for nature" 8 and makes its defense an ethical imperative indissociable from respect for the dignity of the individual.

${ }^{3}$ E.B. Tylor, Primitive Culture, vol. 1, New York 1920, p. 1.

${ }^{4}$ D.H. Brown, Principles of Language Learning and Teaching, $4^{\text {th }}$ ed., London 2000, p. 176-177.

5 A.B. Fenner, Cultural Awareness, [in:] Approaches to Materials Design I European Textbooks: Implementing Principles of Authenticity, Learner Autonomy, Cultural Awareness, Ed. D. Newby, Graz 2000, p. 144.

6 UNESCO Universal Declaration on Cultural Diversity, Johannesburg 2002, p. 1.

${ }^{7}$ Ibidem, p. 62.

8 Ibidem. 
The Declaration aims both to preserve cultural diversity as a living, and thus renewable treasure that must not be perceived as being an unchanging heritage but as a process guaranteeing the survival of humanity, and to prevent segregation and fundamentalism which, in the name of cultural differences, would sanctify those differences and so counter the message of the Universal Declaration of Human Rights.

The Universal Declaration makes it clear that each individual must acknowledge not only otherness in all its forms but also the plurality of his or her own identity, within societies that are themselves plural.

Only in this way can cultural diversity be preserved as an adaptive process and as a capacity for expression, creation and innovation. The debate between those countries which would like to defend cultural goods and services "which, as vectors of identity, values and meaning, must not be treated as mere commodities or consumer goods" ${ }^{\prime \prime}$, and those which would hope to promote cultural rights has thus far been surpassed, with the two approaches brought together by the Declaration, which has highlighted the casual link uniting two complementary attitudes.

One cannot exist without the other. The Declaration, accompanied by the main lines of an action plan, can be an outstanding tool for development, capable of humanizing globalization.

We need to teach others how truly diverse our world is on every step we take, because let's face it we are as diverse as the planet we live on. As Albert Einstein once said "somebody who only reads newspapers and at best books of contemporary authors looks to me like an extremely near-sighted person who scorns eyeglasses. He is completely dependent on the prejudices and fashions of his times, since he never gets to see or hear anything else". ${ }^{10}$

Javier Perez de Ceullar11 in his report "Our creative diversity" emphasizes that this title is very significant. The first word "our" puts the accent on the community, the world - a great community covered by actions, the effects of which are felt everywhere. It is not so that if anything happens to us it doesn't matter for people living on another continent because everything is connected by complex constraints, and the fate of each of us is entwined within a network of different determinants and consequences. Problems that

${ }^{9}$ Ibidem, p. 63.

${ }^{10}$ A. Einstein, http://www.goodreads.com/quotes/22302-somebody-who-only-readsnewspapers-and-at-best-books-of, [date of access: 20.07.2016].

${ }^{11}$ Twórcza różnorodność świata - Raport Światowej Komisji ds. Kultury i Rozwoju UNESCO 1992. 
arise extend not only beyond the framework of one country, or even continent, but become global problems.

The word "creative" indicates that it is co-created by the people living in the world, who are the driving force behind the ongoing changes. The third word "diversity" refers to the issue of cultural identity - way of life, customs, beliefs. This dimension of identity differentiation need not be nullified by the formation of the world community, however, its existence depends on how much we want to know about and understand others.

The Trans-Siberian train is Russia's answer to the USA melting pot as you can meet people from all walks of life and you spend quite some time together. People sleep in four berth compartments in second class, they usually spend all day eating, chatting, and playing games, sleeping, or enjoying the landscape through the window. They often look at the timetable that says at what time the next stop will be. And when the stop comes, they get out, stretch their legs, inspect the bags of the people selling products on the platform, they buy a cake, even in the middle of the night. Some people travel for the whole 6 days it takes to cross Russia, others only for a few days, people meet, talk with each other about where they come from, how life is there, it is a rare occasion of meeting people from everywhere in Russia. They feel at home in their compartment, they bring back beers bought at a stop and invite their neighbors as guests for an evening of talk, card games and laughs.

The kind of people travelling in the second class represent the whole country, so it is a great way to become more intimate with the Russian culture. Some examples of people that you can get to know there are:

- Quite wealthy families, they usually manage to get a compartment for all of them together, and they eat all day, play games in the evening, comment on the route, get bored.

- Students native of eastern Russian cities, who study in Moscow and come back home for the summer.

- Army men, younger or older, who cross the Russian continent to go back to their families, or who go to fight in Chechnya or to work in South countries. They travel for free, so they usually choose to be in Second class, as it is more comfortable than the third class communal wagons.

- In the 1st class you meet businessmen, and wealthier people enjoying the privacy of two people compartments.

- In the third class communal "platzcart" wagons you will meet groups of children, and middle class - not so wealthy people travel in communal wagons. 
The United States is home to many cultures and a wide variety of ethnic groups, traditions and values. Aside from Native American, Native Hawaiian and Native Alaskan populations, nearly all Americans or their ancestors settled or immigrated within the past five centuries. Mainstream American culture is a Western culture largely derived from the traditions of European immigrants with influences from many other sources, such as traditions brought by slaves from Africa. More recent immigration from Asia and especially Latin America has added to a cultural mix that has been described as both a melting pot, and salad bowl in which immigrants and their descendants retain distinctive cultural characteristics.

Similarly in Poland we have groups of people, who retain their own distinctive cultural characteristics, a good example would be Kashubians. Kashubians are a West Slavic ethnic group in Pomerania, north-central Poland. Their settlement area is referred to as Kashubia. They speak the Kashubian language, classified either as a separate language closely related to Polish, or a Polish dialect. In analogy to the linguistic classification, Kashubians are considered either an ethnic or a linguistic group.

Studying culture is also useful for teaching other people to understand their own culture. According to Rivers, we all are 'culture bound ${ }^{12}$ ' at some point in our lives - this means that our world view is determined by the values of our own culture. This, unfortunately, can lead to problems when we are confronted with different cultures. Studying culture gives us "liking for the people of that culture"13, "helps avoid stereotypes"14 and should have a bigger part in general education.

\section{Cultural education \\ - how to creatively teach diversity in the contemporary world}

The role of culture teaching in developing our understanding of the fact that all people exhibit culturally-conditioned behavior and that social factors such as age and sex influence the ways in which people speak and behave. Studying culture helps us to become aware of conventions of behavior in common situations in the target language and develops the ability to evalu-

\footnotetext{
12 Rivers cited from: J.M. Valdes (ed.), Culture Bound. Bridging the cultural gap in language teaching, Cambridge 1986, p. 146.

${ }^{13}$ K. Kitao, http:/ / files.eric.ed.gov/fulltext/ED330214.pdf, [date of access: 20.07.2016].

14 Nemini cited from: D. Thanasoulas, http://www.developingteachers.com/articles_ tchtraining/culture1_dimitrios.htm, [date of access: 20.07.2016].
} 
ate and refine generalization about the target culture. A the poet, educator, historian and civil rights activist dr Maya Angelou once said "it is time for parents to teach young people early on that in diversity there is beauty and there is strength".$^{15}$ There are many different ideas teachers have about the problem of cultural education, some teach only the culture of their own country, not going into the details of foreign cultures, even when it comes to language teaching, which is a grave mistake as Kramsch suggests that we cannot be competent in the language "if we do not have an awareness of that culture, and how that culture relates to our own first language/first culture". 16

Teachers sometimes use new as well as old media to teach culture and its diversity. Research I conducted on a group of 120 kindergarten children indicate that already at this stage of education we can effectively implement activities that will allow the child to learn openness towards "others", but also being in harmony with them.

One of the elements implementing these activities can be cartoons (animations) carefully chosen by the teacher. In the lesson plans conducted by teachers AAAHH Real Monsters and Hey Arnold! were used as a basis for further activities for children, in which they use drawings, a mixture of visual and verbal text in letters to friends from other countries, thematic games, verbal and musical improvisations, drama games.

Cartoons are a good example of that. From the dialogue between the Gromble and Oblina from the cartoon AAAHH Real Monsters we have a citation that is as valuable now as it was when the show was still running "Do you know what we call those who are afraid of that which they don't understand?! - Humans".

Another example of cultural diversity, which can be perceived in the media can be found in the Hey Arnold! cartoon. It describes the story of a clever fourth grader Arnold Shortman who lived in the "urban" area of town with his hilarious grandparents in a boarding house full of equally funny characters. He had a football shaped head, a pig named Abner, and an African-American best friend Gerald. There to complicate things was Helga G. Pataki, a brute of a young girl who bullied Arnold while secretly harboring a crush on him. Those three characters were the leads, and stories usually revolved around them with each one receiving a decent amount of screen time.

15 M. Angelou http://voiceseducation.org/content/maya-angelou-0, [date of access: 20.07.2016].

${ }^{16}$ C. Kramsch, Context and Culture in Language Teaching, Oxford 1993, p. 27. 
Hey Arnold! aired from 1996 to 2004. The audience enjoyed seeing Arnold serve as the voice of reason for his colorful and dissimilar friends who always seemed to be constantly scheming. The audience loved seeing his grandmother, a woman with advanced Alzheimer's, who could one day be a martial arts guru and the next day be a spy. However, what the audience appreciated was the diversity that, the director of the show, Craig Bartlett offered to viewers.

Arnold is of Caucasian descent. His best friend Gerald is an AfricanAmerican. Helga's confidante Phoebe is half Japanese, whereas snobbish Rhonda is Welsh-American. Wealthy student Lorenzo is Hispanic, and blond haired, brown skinned Nadine was mixed. However, not only did the show boast racial diversity, it was a diverse period. All viewers knew that Arnold's teacher Mr. Simmons was gay. Bartlett even revealed it in a later interview. Furthermore, the show did not shy away from religious diversity either. Rotund bully Harold was Jewish and received an episode that focused specifically on his bar mitzvah. Variety is the spice of life. With that being said, it does beg the question - why are not more cartoons this diverse?

New Information Technologies are a chance and not the opponent of education's humanistic intentions. Referring for example to Hirsh's statements included in his publication Cultural Literacy. Even though Hirsh did not deal with new technologies while analyzing his statements I found indications that cultural education is the only basis for mutual understanding and agreement between people. That is why we should not deprive children of technology which is an array of engaging tools that this generation of digital natives is growing up with. One such example could be Minecraft a game for PC, Xbox and PlayStation, very popular with children nowadays. I analyzed here its use on the Xbox.

Using Xbox children can connect with friends from all over the world. Not only are they all engaged, but also collaborating, communicating, solving problems, strategizing, and thinking critically to create their own unique world. What I just described in the last sentence is commonly referred to as $21^{\text {st }}$ Century Skills. However, I believe that these skills are paramount to success in the 21 $1^{\text {st }}$ Century and beyond. Children around the world need these skills as well as experiential learning opportunities that allow them to follow their passions while unleashing their innate desire to be creative.

Some of the best learning and bonding conversations technologically savvy parents have with their children are when they explain their rationale and thinking that have gone into creating various Minecraft worlds. The 
learning is evident as children meticulously explain the structure and function of the different worlds they have created. As parents and educators, seeing such creations, discovering the methodology and basking in children's enthusiasm never gets old. In my opinion, this is learning at its finest, driven by authentic engagement, passion and creativity.

As the German philosopher Friedrich Nietzsche once said "at bottom every man knows well enough that he is a unique being, only once on this earth; and by no extraordinary chance will such a marvelously picturesque piece of diversity in unity as he is, ever be put together a second time" ${ }^{17}$

\section{Conclusion}

The report "Our creative diversity" is preceded by the motto "Development deprived of human and cultural context is a development deprived of spirit". 18

The values of culture, which different groups and communities bring, are very strongly exhibited in this report. The heart of the report is not only comprised of cultural dialogue or tolerance for otherness, but also the issue of respect for otherness, which should improve us.

We stand before the next educational challenges. Intercultural education should allow children to orient themselves in every culture - their own and foreign, subjecting it to critical evaluation and consequently making thought out choices. Such an education enables young people to understand that diversity is the natural state of things. It can lead to thinking about enriching the role of otherness and diversity, teach the value of every human being but also the values of community.

\section{BIBLIOGRAPHY}

Angelou M., Maya Angelou, http://voiceseducation.org/content/maya-angelou-0, [date of access: 20.07.2016].

Brown D.H., Principles of Language Learning and Teaching, $4^{\text {th }}$ ed., Longman, Pearson Education Limited, London 2000.

Einstein A., http:/ / www.goodreads.com/quotes/22302-somebody-who-only-readsnewspa pers-and-at-best-books-of, [date of access: 20.07.2016].

17 F. Nietzsche, Untimely mediations, Cambridge 1997, p. 125.
18 Twórcza różnorodność świata - Raport. 
Fenner A.B., Cultural Awareness [in:] Approaches to Materials Design I European Textbooks: Implementing Principles of Authenticity, Learner Autonomy, Cultural Awareness, Ed. D. Newby, European Centre for Modern Languages, Graz 2000.

Gallagher C., Minecraft in the Classroom: Ideas, inspiration, and student projects for teachers, Peachpit, United States 2014.

Garrelts N., Understanding Minecraft: Essays on Play, Community and Possibilities, McFarland, Jefferson, North Carolina, United States 2014.

Hinkel E. (ed.), Culture in second language teaching and learning, Cambridge University Press, New York 1999.

Kitao K., Teaching Culture in Foreign Language instruction in the United States, http:// files.eric.ed.gov/fulltext/ED330214.pdf, [date of access: 20.07.2016].

Kramsch C., Context and Culture in Language Teaching, Oxford University Press, Oxford 1993.

Levine E., 'Arnold' deals with life in the big city, Houston Chronicle April 27, Hearst Corporation 1997.

Nietzsche F., Untimely mediations, Cambridge University Press, Cambridge 1997.

Nisbet R.A., Encyclopaedia Britannica, https://www.britannica.com/topic/socialscience\#ref423691, [date of access: 20.07.2016].

Obracht-Prondzyński C., The Kashubs today : culture, language, identity, Instytut Kaszubski, Gdańsk 2007.

Paranyushkin D., People in the Trans-Siberian Train, http://waytorussia.net/Trans Siberian/Life.html, [date of access: 20.07.2016].

Thanasoulas D., Language and Culture, http://www.developingteachers.com/articles_ tchtraining/culture1_dimitrios.htm, [date of access: 20.07.2016].

Twórcza różnorodność świata - Raport Światowej Komisji ds. Kultury i Rozwoju UNESCO 1992.

Tylor E.B., Primitive Culture, vol. 1, J.P. Putnam's Sons, New York 1920.

UNESCO Universal Declaration on Cultural Diversity, Johannesburg 2002.

UNESCO World Report Investing in Cultural Diversity and Intercultural Dialogue, United Nations Educational, Cultural and Scientific Organization, Paris 2009.

Valdes J.M. (ed.), Culture Bound. Bridging the cultural gap in language teaching, Cambridge University Press, Cambridge 1986. 